\title{
The Implementation of Clique Strategy in Regrouping Program to Increase Farmer's Interest and Loyalty in Sugarcane Farming
}

\author{
Danang Permadhi and Trikuntari Dianpratiwi* \\ Division of Social Economy, Indonesian Sugar Research Institute (ISRI), Indonesia
}

(Received November 5, 2019; Accepted December 2, 2019; Published December 12, 2019)

\begin{abstract}
The area size of sugarcane planting nationally shows a decrease. This is also marked by a decrease in the interest of farmers planting sugarcane and low loyalty to the sugar factory. In 2014, the government established a sugarcane management regrouping program. The regrouping program provides benefits for the efficiency of sugarcane planting, more effective in cutting and transport processes, forging farmer group and sugar factory, and increasing farmers' loyalty to the sugar factory. The weakness of the regrouping program is that it emphasizes technical aspects only. The criterion of the social aspect is essential because this always saves problems related to communication networks and establishing cooperation. Through the clique strategy, this can conduct a communication network analysis in regrouping. Regrouping programs can build social interaction and communication networks. The form and level of communication network structure in the regrouping program can place actors or farmers build communication networks and cooperate in sugarcane farming. Understanding the role of cooperation networks between farmers or groups determines the success of regrouping sugarcane.
\end{abstract}

Keywords: interest, loyalty, regrouping, communication networks, clique strategies

JEL Classification: P32, O35, Q18

\section{INTRODUCTION}

Sugar is one of the staples consumed by the community and national strategic commodities. In general, Indonesian people consume sugar as a source of energy, flavoring and raw materials for the food and beverage industry. The uniqueness of sugar influences policies and systems that are specific to its production, marketing, and consumption. This strategic position makes sugar prices have a level of sensitivity and volatile fluctuations so that they can disrupt the national economy.

Government efforts to encourage the increase in sugarcane productivity have been carried out in many fields, including the provision of soft loans, sugarcane seed assistance, and fertilizer price

\footnotetext{
* Corresponding author email:

trikuntari.dianpratiwi@gmail.com

ISSN 2615-6075 online; ISSN 2615-6946 print

@UWG Press, 2019

OJS http://publishing-widyagama.ac.id/ejournalv2/index.php/jsed/
}

subsidies. However, these efforts have not been able to provide solutions for sugar self-sufficiency and increase the welfare of farmers. The understanding of sugar self-sufficiency requires the maximum role of all agribusiness subsystems, especially on the farm side, where farmers are the main actors. Subiyono (2014) said that the success key of national sugar production lies in the role of sugarcane farmers since it is the majority of the raw material of sugarcane cultivated by farmers on their farmland. In 2016, the area of farmer's sugarcane land constituted $65 \%$ of the national sugarcane land area (Ministry of Agriculture, 2017). Therefore, farmers can be said to be an important figure for the development of the national sugar industry.

Data of Central Statistics Agency (2017) shows that from 2013 to 2017 there was a decline in national sugarcane production (Figure 1). In 2013 the domestic sugarcane production was 470.94 thousand hectares. It became 420.15 thousand hectares in 2017 and decreased by 50.79 thousand hectares or $10.78 \%$. This figure proves the interest 
of farmers growing sugarcane is lowering. The emergence of a person's interest includes pleasure and excitement in an object for a specific reason. Interest in sugarcane because it is more easily cultivated compared to horticultural crops or other food commodities.

There is a gap in the application of sugarcane cultivation technology at the farm level which is also a factor causing a decline in sugarcane production every year. The problem of technological gaps can be influenced by; (i) problems with technology transfer to farmers; (ii) farmer internal factors such as an area of arable land and income continuity; and (iii) institutional issues in production. The dissemination of agricultural research innovations is a vital communication activity in driving the process of distribution and application of technology in a rural social system. The benefits will flow to the community if the technology is adopted by farmers. Therefore the management of communication between farmers is needed so that it can create institutional strengthening of sugarcane farming.

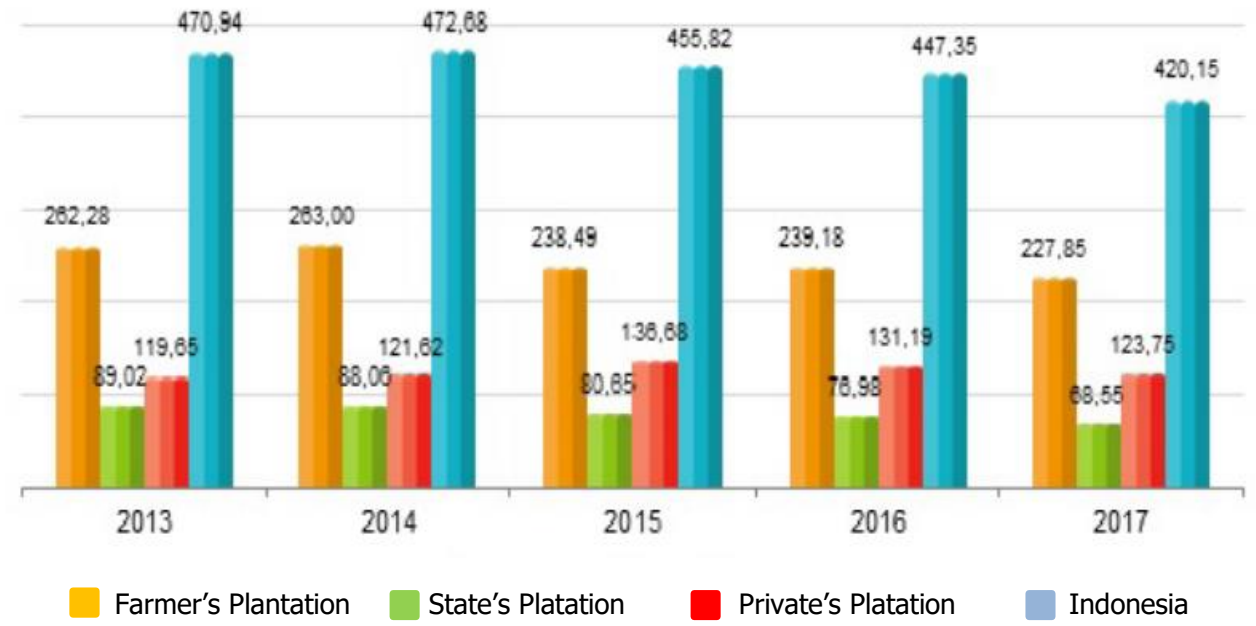

Figure 1. The area of sugarcane plantations in Indonesia

(Source: (BPS, 2018))

Subiyono (2014) stated that relations between farmers and related stakeholders, especially sugar factory have relatively improved. However, it is not well-managed, and still has opportunistic attitudes from both parties. Relations and cooperation between farmers and sugar factory should be wellsystemized in all fields, from upstream to downstream. Collaboration should be established from pre-planting to marketing sugar. At that level, a general pattern of development of the sugarcane industry should be developed. The development of the sugarcane industry should start with sincere communication among all parties.

Based on the problems, it is necessary to have the concept of institutional strengthening of farmers for increasing the interest and loyalty of farmers to cultivate sugarcane. Communication network analysis is one of the institutional strengthening strategies through the clique (group) strategy method based on the relations and cooperation between farmers. Communication network analysis is defined as a set of relations among actors (people, institutions, companies, and countries) with one another in particular social structures (Eriyanto, 2014). It can provide a real picture of the strengths that exist in an organization. Informal relations between actors will form cliques and then produce the role of actors (leaders, bridges, links, adhesives or isolators) in an organization.

This study aims to describe the clique strategy through communication network analysis to strengthen the regrouping program to increase the interest and loyalty of sugarcane farmers. The 
clique strategy is applied in farmer groups socially and technically through regrouping program of sugarcane farmland. The character of the farmer group displays the mapping of farmers' communication networks in sugarcane farming. The communication network provides a control mechanism for management's technical implementation, from cultivation to the marketing of sugarcane. The functional grouping has applied in sugarcane cultivation with the concept of regrouping. The clique strategy is carried out to strengthen the institutions of sugarcane farmers through the analysis of communication networks by paying attention to the psychological relationship between farmers and institutions.

\section{THE CONCEPTUAL FRAMEWORK}

\section{The Interest of Farmers Planting Sugarcane}

The interest is an individual's interest in a particular object that makes the individual himself feel happy with the purpose. The interest is one element of personality that plays an important role in making future decisions. Interest directs the individual towards an object based on feelings of pleasure or displeasure. Feeling of happiness or anger is the basis of interest. The interest in its essence is the cause and effect of experience. Interest develops as a result of an activity and will be used again in the same action. The interest arises when there is attention. In other words, the benefit is the cause and effect of concentration. It also happens to the importance of farmers to plant sugarcane, which is also influenced by interest or feeling of pleasure, attention and needs to plant sugarcane.

Study of the interest of farmers planting sugarcane has conducted. According to Brilianti \& Widjajanti (2019), the factors that influence the interest of farmers in planting sugarcane are divided into internal and external factors. The internal factors are as follows: Formal education correlates with the mindset of sugarcane farmers, i.e. farmers will be more careful in making decisions. Education influences the speed of farmers receiving information or technology adoption related to sugarcane farming. Formal education also influences the activeness of a person in an organization, contributes significant opinion, and provides benefits to farmers. Nonformal education also correlates with the decisions or interest of farmers in sugarcane farming. Nonformal education such as training, counseling or field schools involved participation of extension workers, private sectors, NGO, research institutions and related agencies. The purpose of education is to increase knowledge and skills of the farmers. Land tenure has a positive relationship with the interest of the decision of farmers to plant sugarcane. The larger the size of farmland, more extensive control of sugarcane land, the higher the benefit of farmers planting sugarcane. It is because sugarcane includes in the type of plants that can obtain higher profits by expanding land tenure.

The external factors significantly affect the interest of farmers in planting sugarcane. First, the role of the closest people. When farming sugarcane, farmers requires motivation, support or capital assistance from the people closest to him who can make farmers more confident to decide on sugarcane farming. Besides, someone who sees the closest people succeed in sugarcane business will be interested in participating in the same activity. Second, the role of cooperatives. The role of the sugarcane farmers cooperatives is considered necessary for a provision such as the distribution of inputs, savings, and loans for sugarcane farming funds and channel assistance from the government. Third role is extension service. Farmers consider the role of the extension worker in deciding or conducting sugarcane farming as a medium of transfer of knowledge and information, channeling government assistance and skills in sugarcane farming. The more frequent counseling happens, the more increase the attitude of farmers to continue to hone and improve skills in managing plantation. Fourth is natural conditions. One of factors that is difficult to be controlled by humans is natural conditions. Farmers assume the optimum growth of sugarcane supported by the surrounding natural conditions, including soil fertility, irrigation, and regional climate. Fifth, access to capital is one of the keys to success in farming business. It is farming with capital assets that are easily in demand by farmers. The ease of access to capital in sugarcane farming from cooperatives, sugar factory or the bank with soft interest makes farmers are interested and decides on sugarcane farming. Sixth role is sugar prices. The decline and 
increase in sugar prices have technical, social and economic impacts. Like the government decision in May 2017 issued a decree to decrease the highest retail price (HET), which affected the purchase price of sugar at the level of sugarcane farmers from Rp. 11,000 per kilogram.

\section{The Loyalty to the Sugar Factory}

Farmer loyalty will arise if there is a relationship between agricultural actors with other constructive factors (Lukito, 2017). Sugarcane is a plant that requires cooperation in cultivation by farmers. According to Mubyarto (1984), discipline and loyalty of members are needed to achieve high sugarcane production with increased planting, maintenance to harvesting. The attitude of farmers whose partner will be loyal to the company (sugar factory) if the partnership is mutually beneficial. The benefits of a business that help each other (Hafsah, 2003), are: (i) increasing productivity; (ii) quantity, quality, and continuity guarantees; (iii) increasing work efficiency; (iv) risk-sharing; (v) reducing social inequality; and (vi) increasing economic empowerment.

According to Widjajanto (2013), one of the factors that determine the success of sugarcane farming is the partnership with sugar factories. A good partnership relationship will have an impact on increasing farmer loyalty to the sugar factory so that the supply of raw sugarcane will remain guaranteed. The existence of particular businesses from the partnership between sugar factory and farmers includes two dimensions, (i) sugarcane farming that is more profitable when compared to other commodities and (ii) service certainty from the company that can be calculated. Guidance and services that meet the needs are considered important in fostering loyalty in partnering. Therefore, sugar factory officers with qualified technical abilities in coaching, administration, supervision, and evaluation are needed. Excellent factory performance also provides provisions for sugar factory officers in carrying out their tasks in dealing with farmers. Efficient plant performance can improve competitiveness with other sugar factories in obtaining raw sugarcane raw materials. A higher yields and farmers' profit, farmers will be more motivated to supply their sugarcane to efficient sugar factories.
External factors that determine the interest and loyalty of sugarcane farmers are sugar prices, service quality policies, and facilities at sugar factory (Ardianto, 2010). The loyalty factors can be influenced by price, service quality and convenience policies. Factors related to the determination of sugar prices and yields affect the loyalty of sugarcane farmers. Farmers feel safe if the decision of sugar content in cane (rendemen) is done objectively and is in favor of the farmers. Sugar factory service quality also has an impact on the loyalty of sugarcane farmers. A large number of farmers conflict with sugar factories because of constraints in limiting SPTA (Slash and Cut Transportation Orders). It has caused many farmers to sell their sugarcane to traders (pokpokan) or the brown sugar industry. Ironically, at the same time, sugarcane traders quickly get the SPTA. Sugar factory officials are not competent to solve the problem of sugarcane farmers and suspected of behaving in moral hazard in the distribution of SPTA.

The facility factor has a positive relationship on the loyalty of sugarcane farmers. The facility referred to is the ease of obtaining sugarcane seeds and tractor rental. Another necessary convenience facility is the availability of fertilizers which usually experiences scarcity. The hope of farmers related to the sugar mill policy is the resolution of the difficulties of sugarcane farmers so that they can provide a sense of security and comfort for farmers.

\section{Clique Strategy through Communication Network Analysis}

Grouping farming is essential in efforts to increase sugarcane productivity. Within the farming group, there is a positive interaction between farmers to contribute to the success of sugarcane farming. Within groups, social relationships and interpersonal communication processes are formed. Understanding of social relations can be learned through the study of communication networks, for example how people send messages to each other and engage in communication networks.

Communication network, according to Rogers \& Kincaid (1981) is a network consisting of individuals who are interconnected, which are connected by the flow of communication and form specific 
patterns. Eriyanto (2014) distinguishes communication networks into two types, namely formal and informal communication networks or also referred to as parasitic communication. So, the understanding of communication networks is a series of relationships between individuals in a social system through the exchange of information, to form patterns or models of communication in a communication network.

Communication networks have unique characteristics in the study of social communication. According to Eriyanto (2014), the uniqueness of a communication network includes several things. First, it focuses on relationships and not attributes. The communication network approach believes that individual behavior or attitudes are the results of networks not because of the characteristics of the actors. Each actor/individual cannot be described as independent but somewhat dependent/independent of the interplay between factors on social networks. Second, it is non-group networks. The assumption in communication network research is that a person is part of a particular system, and not from a group. Every individual is a member of a group, and that individual can have a broader link than a particular group. Third, communication relationships are formed in the context of individual relationships by relationships between factors interrelated. Fourth is relationships and structure. In the analysis of communication networks, the perspective of the actor's position and the relationship of the actor is determined by the actor's seat in the structure. Network analysis links actors, actors with groups and actors with the overall network system (Monge, 1987).

Rogers \& Kincaid (1981) argues that communication network analysis is a research method for identifying communication structures in a system, which uses data about communication flow and types of interpersonal relationships. Several things can be done in the analysis of communication networks, namely: (i) identifying standards in a system; (ii) identifying a person's specific role in the network such as, connectors, bridges/hubs, stars, eigenvectors, isolated and others; (iii) measuring indicators (indexes) of communication structures such as clique continuity, clique openness, clique integration and so on.
Meanwhile, a clique is part of a system (subsystem) in which some actors interact relatively more with each other than other actors in a communication network system (Rogers \& Kincaid, 1981). The clique phenomenon combines cohesive components as clusters and then combines clusters into larger communities under the direction of certain management functions (Wan, Liao, \& Zhu, 2008) (Palla, Derényi, Farkas, \& Vicsek, 2005). There are three criteria to identify these cliques, namely; (i) each clique consists of at least three actors; (ii) each group member must have a $50 \%$ connectedness in the group; (iii) all direct and indirect actors must be interconnected through a continuous and comprehensive dyadic or triadic chain of relationships in clique (Rogers \& Kincaid, 1981).

Clique identification can find out how the communication structure formed, and the degree of communication structure measured. Besides, cliques can also track the level of innovative members by measuring the level (degree) of openness from the clique (Clique Openness). Through the pattern of relationships between its members, the openness of a clique with members outside the boundary of the clique can be observed. The higher the clique member relationship with other members outside of the clique, the higher the degree of clique transparency that is formed. The higher degree of clique openness means more information received by members in the clique and vice versa (Syafril, 2002).

Rogers \& Kincaid (1981) state that in the communication network involve the roles of such actors as ; (i) liaison officer (LO), which is an actor connecting two or more groups (cliques), but LO is not a member in one group (cliques); (ii) gatekeeper, which is an actor that filters out information before it is communicated to other group members (cliques); (iii) bridges, that is group members (cliques) associated with other groups (cliques); (iv) isolates, those who are excluded from a network component; (v) cosmopolitan, that is group members connecting groups with other groups or outside parties; (vi) opinion leader, that is the actor who is an opinion leader in a group or sub-group (Figure 2). 


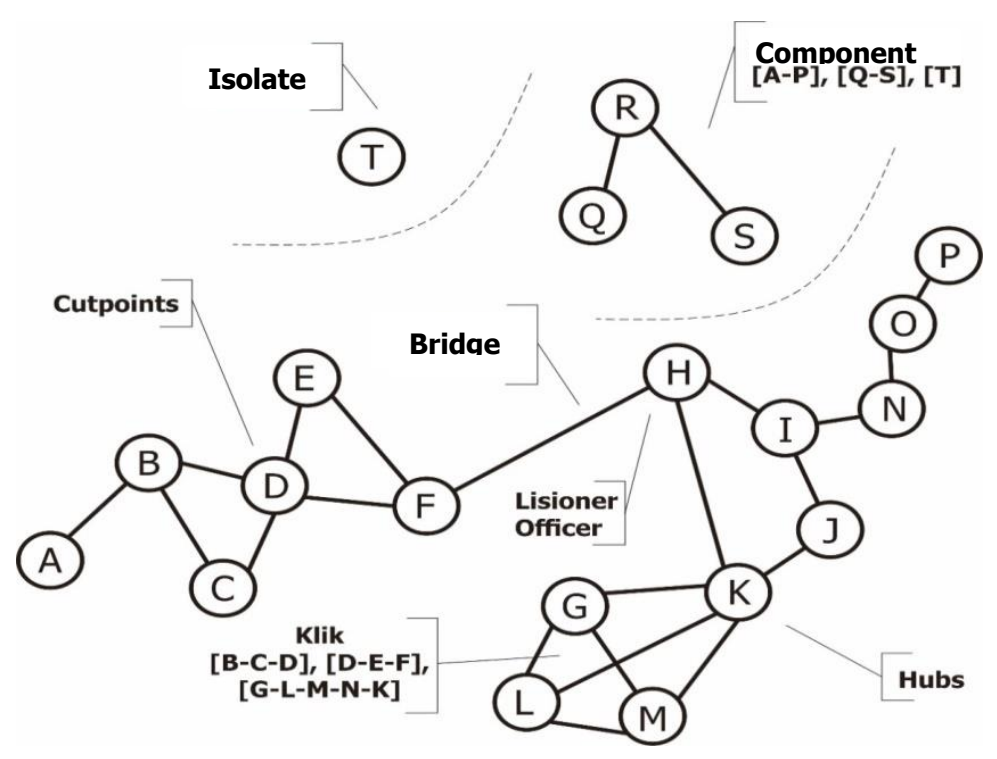

Figure 2. Communication network structure (Source: Eriyanto, 2014)

Stages of data processing using a clique strategy through the analysis of communication networks follow the scope of the study. The range of communication network analysis comprises overall analysis (complete network) and ego network. The analysis of the overall network consists of (i) creating a communication network questionnaire; (ii) recapitulating of communication network questionnaire data; (iii) making sociometry (matrix of interactions between factors); (iv) transformating sociometric data (initial or display data, symmetry or binary / dichotomy); (v) making a sociogram (picture of interaction between factors); and (vi) analyzing communication network data (complete ego network analysis) (Eriyanto, 2014). The results of applying the clique strategy through communication network analysis are presented in Table 1.

The network analysis method also has weaknesses. This relates to the position of a passive actor, who is deemed not to have the ability to change his status in the social structure (Borgatti \& Halgin, 2011; Borgatti, 2012). In this position, the communication network is less concerned with how the actor sees his position and how the actor assesses the status of other actors. In addition, communication networks also pay less attention to network structure dynamics because network structure positions are always dynamic or changing (Rogers \& Kincaid, 1981), dynamics or changes in communication network structure can be the strength of network methods However, studies related to changes in network structure are relatively longitudinally limited. The last drawback is the potential for multiple hermeneutics, i.e. an actor may be able to change his position or role in the network structure if there are actors who know the research being conducted (Borgatti \& Halgin, 2011).

\section{Regrouping Program of Farmland}

Individual farmer group activities make it difficult for sugar factory to carry out technical assistance in sugarcane farming (Syahyuti, 2003). Farmer groups are institutions formed by sugarcane farmers and are flexible entities related to relationships within or outside the group (Asopa, Beye, \& Nations, 1997). Therefore, flexible farmer group institutions can be more receptive to regrouping efforts in order to improve the collective performance of farmer groups (Roesmanto, Dianpratiwi, \& Nahdodin, 2008). The existence of regrouping farmer groups depends on the effectiveness of the benefits and costs received by group members. The Ministry of Agriculture has established a policy to increase sugarcane planting 
by regrouping the management of farmers' land in 2014 (Ferhat, Mulyo, \& Irham, 2018).

In Indonesia, the definition of regrouping is divided into two. First, it is related to the regulation of agricultural exploitation. It is regrouping which involves the active role of farmers through the change in the business, which was previously individual to form a farmer group. Second, it is related to the regulation of land boundaries. It is an effort to restructure the boundaries of land parcels into an area of land management that is previously separated in groups (without the need for new forms of farmer groups).

Table 1. The Implementation of the Clique Strategy through Communication Network Analysis

\begin{tabular}{lll}
\hline \multirow{2}{*}{ Level of Analysis } & & \multicolumn{1}{c}{ Study Design } \\
\cline { 2 - 3 } Actor Level & Complete Networks & Ego Networks \\
& a. Degree Centrality & a. Network Closure \\
& b. Closeness Centrality & b. Structural Holes \\
& c. Between Centrality & c. Tie Strength \\
d. Eigenvector Centrality & \\
\hline Clique Level & a. Component & a. Brokerage \\
& b. Clique & b. Homophile \\
& c. N-Clique & c. Structural Equivalence \\
& d. K-Core & \\
& e. K-Plexus & a. Size \\
\hline System Level & a. Size & b. Density \\
& b. Density & c. Distance \\
& c. Reciprocity & \\
d. Distance &
\end{tabular}

Regrouping land should support the use of mechanization technology effectively, efficiently and economically. There are several problems found in the cultivation technique, such as: (i) structuring sugarcane varieties; (ii) having poor cultivation technical implementation; (iii) competing for land use; and (iv) having no SBM quality standards (sweet, clean and fresh) in sugarcane felling. According to (Padilla-fernandez \& Nuthall, 2009), the application of mechanization technology can cut all unnecessary activities and costs, so that the farming business runs more quickly and efficiently. Land regrouping management is one of the efforts to improve the welfare of farmers, especially small-scale sugarcane farmers (Pranadji, 2003).

Studies show the benefits of regrouping land management among other SBM quality standards (sweet, clean and fresh): (i) increasing farmers' interest in planting sugarcane, and supplying raw materials for sugar factory; (ii) cutting and transporting process and guaranteed by the sugar factory; (iii) increasing sugarcane farmers' loyalty to sugar factory, in line with the development of farmers by sugar factory; (iv) effectiveness of subsidies from sugar factory for sugarcane farming; (v) providing priority arrangement and timetable for felling sugarcane, and providing net income (SHU); (vi) increasing bonding or togetherness of members, and facilitating oversight mechanisms from threats of crop failure or sugarcane fires (Roesmanto et al., 2008) (Cay, Ayten, \& Iscan, 2010).

The regrouping work scheme involves the active participation of three actors, namely sugar factory, farmers and providers. Sugar factory has the role of registering farmland, providing loans to farmers and helping infrastructure facilities and farmland regouping. Regrouping member farmers register cane to the sugar factory, signing a cooperation contract to implement the regrouping program with full mechanization of cultivation techniques. The provider supports the cultivation of sugarcane planting from land cultivation, maintenance, irrigation to the process of cutting, loading and transporting. Moreover, providers should provide and facilitate mechanization tools and machines according to farmers' needs. If a mechanized technology tool or machine is not available, an attempt is made to lease it under the provisions of 
the sugar factory as the person in charge (Ferhat et al., 2018). The relationship scheme between the three actors is presented in Figure 3.

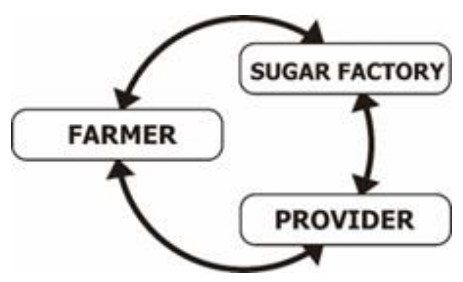

Figure 3. Work pattern scheme

Regrouping management requires the institutional role of Team Work Cane Farming (TWCF). TWCF is part of institutional engineering, combining at least ten farmer groups with an area of at least 50 hectares of regrouping based on overlays or blocks, and is led by a group coordinator (Roesmanto et al., 2008). The effectiveness of regrouping performance is strongly influenced by the leadership of the group coordinator (Chen et al., 2017). A coordinator has the task of managing sugarcane farmland from land management to cutting and transporting assisted by regrouping members as work units. Group members are not only treated as objects but are respected in dignity as subjects to plan, manage and improve the effectiveness and efficiency of group performance (Mubarak, 2010).

Farmer regrouping performance results need to be monitored to produce an increase in sugarcane production. The qualitative measurement parameters can be SBM criteria, namely: (i) sweet, meaning that sugarcane is cut in optimal conditions; (ii) clean, meaning that sugarcane is cut clean from litter (dry leaves), roots; (iii) fresh, meaning that after being cut down it must be immediately ground to a sugar factory. Quantitative parameters using the value of the weight of sugarcane production, sugar content and net income (SHU) members of farmer groups. Research by (Roesmanto et al., 2008) in the sugar factory areas of Tasikmadu, Ngadirejo, Tersana Baru and Jatit Tujuh, shows that regrouping farmland can increase freshness, maturity, production of sugarcane weights, and net income of farmer groups. Meanwhile, Ferhat et al (2018) measures the performance of the implementation of sugarcane regrouping in the Gempolkerep
Mojokerto sugar factory area, using indicators of production factors. These factors are land area, labor flow in the use of seeds, fertilizers and pesticides. The results showed that sugarcane regrouping had not worked optimally, excessive use of ZA fertilizer, inefficient use of seeds, mechanization technology did not work optimally, and weak in management control.

In principle, the implementation of the sugarcane regrouping program still requires a lot of evaluation or an increase in the role of the actors involved (farmers, sugar factory and providers). The regrouping program also needs to be supported by management control to focus and maintain the achievement of the benefits and objectives of the program. The shortcomings of the regrouping program generally only focus on the technical issues of sugarcane cultivation or planting without regard to social aspects. The effectiveness of regrouping program performance is determined by the group coordinator and the role of group members, who must be actively involved and work together to produce improved group performance. The evaluation of the sugarcane regrouping program continues to be done by maintaining team collaboration with intensive communication. Participation in regrouping program is expected to increase mutual awareness and produce concrete solutions to solve problems (Ferhat et al., 2018)

\section{STRENGTHENING THE REGROUPING PROGRAM WITH THE CLIQUE STRATEGY}

Efforts to strengthen the regrouping program require specific strategies to find benefits in sugarcane farming. These are influenced by the attitude of farmers looking at regrouping, changes in external conditions, technical mechanisms of cultivation and farmland management. The right strategy will require continuous and gradual improvement so that it can meet the increase in the quality and quantity of sugarcane.

The indicators to measure the performance of regrouping programs need to involve socially to increase farmers' interaction in regrouping programs. Team Work Cane Farming (TWCF) has the role in optimizing farmer performance through the relationship of group coordinators with sugar mill officials, providers and their group members. Regrouping program performance indicators can be 
done by using the clique strategy through communication network analysis.

Syafril (2002) states that individual characteristics have a significant influence on communication networks, associated with farming experiences, technological perceptions, and cosmopolitan attitudes. However, the communication network does not significantly affect the production and income variables. Besides, the level of individual integration, clique openness and system openness in the communication network greatly influences the reception and exchange of information, which in turn affects the rate of adoption.

Permadhi (2017) argues that the farmer's age and size of agricultural land have real influence on the communication network. The higher a person's age, the more he receives respect by many village elders and forms a broader communication network (Chen et al., 2017). Furthermore, the larger the area of cultivation, the stronger the control of management (centrality) of land to produce productivity and income. Management control requires cooperation and communication networks with interested parties.

In addition, agriculture with large-scale land requires the support of broader communication networks, especially to implement innovation and technology adoption. Rogers \& Kincaid (1981) state that the dynamics in communication networks are not a weakness of communication network studies, but as a control tool to be more careful in making decisions or policies regarding the application of new technologies or innovations.

Steps to implement the regrouping program with the clique strategy can be done before and after the regrouping program runs. The main purpose of implementing the clique strategy is as a social control tool to ensure regulation of sugarcane farmers. Before the regrouping program runs, the clique strategy analysis intends to find out the shape and degree of the communication structure. Based on the results of the analysis, the regrouping program method or regulation is carried out based on the spread of land or adjacent garden blocks.

In the initial stage, data or position of the actor or farmer has been obtained along with adjacent landscapes without observing the closeness or social interaction between sugarcane farmers. From the results of the analysis of the communication network before the regrouping program, it can be found that the recommendation of the actor or farmer with the highest actor is centrality value (Chen et al., 2017). They are the actors who have the highest links and connect to many other actors (farmers).

On the other hand, it is also found that actors who have few links, separated or isolated from group members. They need to get closer to actors who have eigenvectors or the ability of intermediaries to enter the communication network. Prell (2011) and Borgatti (2012) believe that the position of an actor as an intermediary has the most important role because he will determine the membership of a network and can connect two different groups. Besides, intermediary actors (farmers) will enjoy the benefit from their position because they can control the flow of information, filter information that enters the network, and can manage information to achieve the benefits and objectives of the regrouping program.

The next step is to analyze the clique strategy after the regrouping program works. This strategy is carried out by analyzing the communication network to measure the shape and degree of the structure of the communication network. This strategy is expected to have a positive impact not only in improving productivity and quality of technical management of sugarcane cultivation, but also socially impacting on the formation of cooperation and loyalty, especially between farmers and sugar factory. Farmer loyalty in regrouping program can be a measure of attitude, motivation, and teamwork to improve the management of sugarcane farming.

\section{CONCLUSION AND SUGGESTION}

Government efforts to realize sugar selfsufficiency and increase farmers' welfare have not shown optimal performance. In the period 2013 to 2017 , there was a $10 \%$ decline in the area of national sugarcane plantations. It also indicates a decrease in the interest of farmers planting sugarcane and problems of cooperation and farmers' loyalty to the sugar factory. One of efforts to solve the problem is through institutional efforts 
through the sugarcane land regrouping program. The regrouping program is also beneficial for the efficiency of sugarcane cultivation, as well as increasing farmers' cooperation and loyalty to sugar factory.

Efforts to strengthen the institutional regrouping program are operated through a clique strategy. The clique strategy is carried out through communication network analysis in the group results of regrouping. The results of the sugarcane regrouping program include land management with a higher block area (minimum 50 ha), better management of cultivation and application of production factors. The land regrouping program can be evaluated through technical indicators such as the value of the weight of sugar production, sugar content and net income (SHU) members of farmer groups; or through SBM criteria of sweet, clean, fresh of cane tuber.

The regrouping program importantly also impacts social aspects, can build cooperation between farmers, between farmer groups, and collaboration with sugar factory and providers. Through the clique strategy, the regrouping program can build social interaction and communication networks. The form and degree of communication network structure in a regrouping program can lead an actor or farmer to build a communication network and optimize its role to provide benefits in sugarcane farming.

The sugar factory has a vital position in the communication network, while at the same time giving its role optimally supporting the regrouping program. Sugar factory improves the quality of their officers in technical management, farm business assistance, and improve management services for the process of cutting and transporting sugarcane farmers.

\section{REFERENCES}

Ardianto, Y. (2010). Analisis Harga Pasok, Kualitas Layanan dan Kemudahan Terhadap Loyalitas Petani Tebu Gondang Legi Kab. Malang. Iqtishoduna - Jurnal Ekonomi \& Bisnis Islam, 6(1), $1-16$. https://doi.org/10.18860/iq.v0i0.311

Asopa, V. N., Beye, G., \& Nations, F. and A. O. of the U. (1997). Management of Agricultural Research: A Training Manual. Rome: Food and
Agricultural Organization of the United Nations. Retrieved from https://books.google.co.id/books?id=iBDbAAAA MAA]

Borgatti, S. P. (2012). Social network analysis, twomode concepts in. In Computational Complexity: Theory, Techniques, and Applications (Vol. 9781461418009, pp. 29122924). Springer New York. https://doi.org/10.1007/978-1-4614-18009179

Borgatti, S. P., \& Halgin, D. S. (2011). On network theory. Organization Science, 22(5), 11681181. https://doi.org/10.1287/orsc. 1100.0641

BPS. (2018). Komoditas Pertanian Sub Sektor Perkebunan Tebu 2017. Jakarta: BPS Pusat, Jakarta.

Brilianti, B., \& Widjajanti, L. (2019). Dampak Penurunan Harga Beli Gula Pada Petani Tebu di Kabupaten Probolinggo. In Pembangunan Pertanian dan Peran Pendidikan Tinggi Agribisnis: Peluang \& Tantangan di Era Industri 4.0. Jember: University of Jember.

Cay, T., Ayten, T., \& Iscan, F. (2010). Effects of different land reallocation models on the success of land consolidation projects: Social and economic approaches. Land Use Policy, 27(2), 262-269. https://doi.org/10.1016/j.landusepol.2009.03.00 $\underline{1}$

Chen, Y. C., Chen, Y. H., Hsu, C. H., You, H. J., Liu, J., \& Huang, X. (2017). Mining opinion leaders in big social network. In Proceedings International Conference on Advanced Information Networking and Applications, AINA (pp. 1012-1018). Institute of Electrical and Electronics Engineers Inc. https://doi.org/10.1109/AINA.2017.147

Eriyanto. (2014). Analisis Jaringan Komunikasi. Jakarta: Kencana. Retrieved from https://books.google.co.id/books?id=iK5oDwAA QBAJ

Ferhat, A., Mulyo, J., \& Irham, I. (2018). Dampak Regrouping Lahan Terhadap Produksi Tebu Petani Berdasarkan Penggunaan Input di Pabrik Gula Gempolkrep Jawa Timur. HABITAT, 29(3), 113-121.

https://doi.org/10.21776/ub.habitat.2018.029.3. $\underline{14}$

Hafsah, M. J. (1999). Kemitraan Usaha: konsepsi dan strategi. Jakarta: Pustaka Sinar Harapan. Retrieved 
https://books.google.co.id/books?id=OPLsAAAA MAA]

Lukito, A. (2019). Loyalitas Petani Tebu Rakyat Berkaitan Dengan Perilaku Petani, Peran Pemerintah dan Pabrik Gula Di Jawa Timur. Paradigma Agribisnis, 2(1), 1-11. Retrieved from http://jurnal.unswagati.ac.id/index.php/JPA/arti cle/view/2231/1349

Monge, P. (1987). The Network Level of Analysis. In C. R. Berger \& S. H. Chaffee (Eds.), Handbook of communication science. Newbury Parks. California: Sage publications. Retrieved from

https://books.google.co.id/books?id=2kdiAAAA MAA]

Mubarak, Z. (2010). Evaluasi Pemberdayaan Masyarakat Ditinjau dari Proses Pengembangan Kapasitas Pada kegiatan PNPM Mandiri Perkotaan di Desa Sastrodirjan Kab. Pekalongan. Diponedoro University, Semarang. Retrieved from http://eprints.undip.ac.id/23734/

Mubyarto. (1984). Masalah Industri Gula di Indonesia. Yogyakarta: BPFE UGM.

Padilla-fernandez, D., \& Nuthall, P. (2009). Input use inefficiencies in the production of sugar cane in Central Negros Area, Philippines: an application of data envelopment analysis. J. Int. Soc. Se. Asian. Agric. Sci., 15, 1-33. Retrieved from

https://researcharchive.lincoln.ac.nz/handle/101 $\underline{82 / 93}$

Palla, G., Derényi, I., Farkas, I., \& Vicsek, T. (2005). Uncovering the overlapping community structure of complex networks in nature and society. Nature, 435(7043), 814-818. https://doi.org/10.1038/nature03607

Permadhi, D. (2017). Strategi Klik Antarpetani Sengon Laut Desa Kucur, Kecamatan Dau, Kabupaten Malan. Brawijaya University. Retrieved from http://repository.ub.ac.id/9235/

Pranadji, T. (2003). Menuju transformasi kelembagaan dalam pembangunan pertanian dan pedesaan. Bogor: Kementan RI.

Prell, C. (2011). Social Network Analysis: History, Theory and Methodology. SAGE Publications. Retrieved from https://books.google.co.id/books?id=BKamSJe8 $\underline{458 \mathrm{C}}$
Roesmanto, J., Dianpratiwi, T., \& Nahdodin. (2008). Rekayasa Kelembagaan Kelompok Tani Tebu Untuk Meningkatkan Pendapatan Petani Dan Produktivitas. Majalah Penelitian Gula, 44(2), 114-228. Retrieved from http://balittas.or.id/intranet/index.php/filedirectory/category/33-mpg-vol-44-no-2-hal-73144-pasuruan-juni-2008-issn-05417406?download=124: rekayasa-kelembagaankelompok-tani-tebu-untuk-meningkatkanpendapatan-petani-dan-produktifitas

Rogers, E. M., \& Kincaid, D. L. (1981). Communication Networks: toward a new paradigm for research. New York: Mac Milland Publishing Co. Inc. Retrieved from https://books.google.co.id/books?id=r3tiAAAAM AAJ

Subiyono. (2014). Sumbangan Pemikiran menggapai Kejayaan Industri Gula Nasional. Surabaya: PT Perkebunan Nusantara $X$.

Syafril, D. (2002). Hubungan Karakteristik Petani Dan Jaringan Komunikasi dengan Adopsi Inovasi Teknologi Sistem Usaha Pertanian Jagung (Studi Kasus: Kecamatan Rambah Hilir Riau). Bogor Agricultural University. Retrieved from

https://repository.ipb.ac.id/handle/123456789/7 $\underline{949}$

Syahyuti. (2003). Bedah Konsep Kelembagaan: strategi pengembangan dan penerapannya dalam penelitian pertanian. Bogor: Pusat Penelitian dan Pengembangan Sosial Ekonomi Pertanian, Badan Litbang Pertanian. Retrieved from

https://books.google.co.id/books?id=yZRWBAA ACAA]

Wan, L., Liao, J., \& Zhu, X. (2008). CDPM: Finding and evaluating community structure in social networks. In Lecture Notes in Computer Science (including subseries Lecture Notes in Artificial Intelligence and Lecture Notes in Bioinformatics) (Vol. 5139 LNAI, pp. 620-627). https://doi.org/10.1007/978-3-540-88192-6-64

Widjajanto. (2013). Keberhasilan Pengembangan Kemitraan Tebu Rakyat Antara Pabrik Gula dengan Petani Tebu. In Penguatan Inovasi Teknologi Mendukung Kemandirian Usahatani Perkebunan Rakyat (pp. 53-65). Jakarta: Balitbang Pertanian RI. Retrieved from http://perkebunan.litbang.pertanian.go.id/wpcontent/uploads/2013/11/perkebunan risalah 5 -NDA-Widjajanto1.pdf 